\title{
Tripling the Income of Rural Youth through Protected Cultivation Structures Repair: A Success Story
}

\author{
R. R. Meena ${ }^{1 *}$, C. B. Meena ${ }^{2}$, K. L. Geanger ${ }^{3}$, A. Kotmire ${ }^{4}$, \\ K. C. Meena ${ }^{5}$ and A. K. Verma ${ }^{6}$ \\ ${ }^{1}$ Horticulture, Krishi Vigyan Kendra, Kota, Rajasthan, India \\ ${ }^{2}$ Plant Pathology, Agricultural Research station, Ummedganj, Kota, India \\ ${ }^{3}$ Entomology, College of Agriculture, Bhilwara, MPUAT, Udaipur, Rajasthan, India \\ ${ }^{4} N A B A R D$, Mumbai, India \\ ${ }^{5}$ Extension Education, Collage of Agriculture, Kota, India \\ ${ }^{6}$ KrishiVigyanKendra, Jhalawar, Agriculture University, Kota, Rajasthan, India \\ *Corresponding author
}

\begin{abstract}
A B S T R A C T
Hi-tech horticulture techniques becomes popular especially poly-house cultivation in the Rajasthan state. It becomes diversifying the way from traditional crops to horticultural crops toearn higher income per capita. But the constraints were there like, the poly house and shade net house become old, damaged and haphazard. In this situation, the farmers depend on big companies for repair and maintenance of poly house and shade net house. But, companies show their interest in establishing a new one as compare to repair and maintenance. Due to the lack of technically skilled persons at the grass-root level, Poly house and Shade net house could not be repaired within time. Skill development training was specially designed to enhance the skill hood of rural youths with various skilled jobs of high tech horticulture structures. In this context it essential to trained youths for the repair of poly house and shade net house and this becomes helpful to generate employment and provide to the job for other youths. Keeping in view the above constraints, KVK Jhalawar was conducted training on repair and maintenance of the poly house and shade net house for 20 youth for 20 effective days with the financial help of NABARD Jhalawar in the year 2016. Now they are helping to poly-house growers as well as apart from the revenue generation, the participants formed a group and they earned 11.95 lakh in 2 year through the repair and maintenance of dozens of Shade net and poly house in Rajasthan and Madhya Pradesh. A total of 157 youths were engaged for 1188 days and earned Rs. 1195677 as a service component. The monitories impact of training was that their income increased from Rs. 250 per day to Rs. 1006 per day.
\end{abstract}

\section{Introduction}

The importance of entrepreneurial resources as a crucial input in the process of economic development has now been widely recognized by scholars and policy-makers. Entrepreneur is a person who initiates an economic activity and manages it successfully. The process through which one becomes an entrepreneur may be termed Entrepreneurship. The myth that the entrepreneur is born in no more valid, because it has been proved that entrepreneur 
can be developed through scientific methods and training thus entrepreneurship development programmes aims at motivating, developing and counselling potential entrepreneur to establish their own enterprise and develop their entrepreneurial skills, knowledge, and competencies.

To find out the success of any training programme a periodic appraisal and evaluation of what is being done is essential so that suitable changes can be made to make the training programme more effective. The concept of vocational training in agriculture through KVK grew substantially due to the greater demand for improved agricultural technology by the farmers. The training programmes were designed to impart the latest knowledge through work experiences by applying the principles of "Teaching by Doing" and "Learning by doing".

The KrishiVigyan Kendra, Jhalawar has directed its efforts towards agricultural development in the district and bringing about entrepreneurship and skills among practitioners of agriculture and rural youth to ensure livelihood security. The farmers of Jhalawar district are diversifying from traditional crops to Horticultural crops for higher returns. Poly house and Shade net house are establishing continuously under Govt. schemes. The Jhalawar district covers 44,000 thousand $\mathrm{M}^{2}$ areas under protected cultivation during the years of 2017-18. The major constraints are in the poly house and shade net house like damaged due to natural haphazard and become old. In this situation, the farmers depend on big companies for repair and maintenance of poly house and shade net house. These companies prefer to establishing new one then repair and maintenance of the old poly house and shade net house. Due to the unavailability of skilled persons for repairing and maintenance of these structures are at the local level.
Therefore, private companies are charging higher prices for this work, which is more expansive and result they did not get repaired in time and sometime the entire crop may get lost. Due to the lack of technically skilled human resources at the grass-root level, poly house and shade net house could not be repaired in time.

In keeping above facts, the KVK, Jhalawar was designed a special 21 days training program to develop high tech horticultural skills in 20 unemployed rural youth on "Repair and Maintenance of Poly House, Shade net and Drip irrigation system" with financial assistance from NABARD. The training designed to impart the repair and maintenance skills to the youth by applying the principles of "Teaching by Doing" and "Learning by doing". Looking at the impact of this training, a study on "Tripling the Income of Rural Youth through Poly house, Shed net and Drip Irrigation System Repairing:" was undertaken.

\section{Materials and Methods}

The Krishi Vigyan Kendra, Jhalawar has directed its efforts towards agricultural development in the district and bringing about entrepreneurship and skills among practitioners of agriculture and rural youth to ensure livelihood security. The present study was purposively conducted on the rural youths which were trained by KVK Jhalawar in filed entitled "Repair and Maintenance of Poly House, Shade net and Drip irrigation system" during the year 2016 by managing funds from NABARD. It was successfully organized for 20 unemployed rural youths(2130-year-old) with the objectives;-(i) To demonstrate and popularize the techniques of protected structures and (ii) To develop entrepreneurship in unemployed rural youths. The quantitative and qualitative information was collected through available records, 
open-ended questionnaire survey and interview schedule. The gathered data were processed, tabulated, classified and analyzed in terms of percent in the light of objectives of the study.

\section{Results and Discussion}

Table 1 depicted that they have been earned 6.25 lakh rupees in one and half years by the repaired of dozen of shade net and poly house in Rajasthan and Madhya Pradesh. A total of 157 youths were engaged for 1188 days during this time. Previously, they earned only 250 rupees per day and now they earned Rs. 1006 per day income as part-time with agriculture. Now they are registering their firm namely "GREEN UDAY" under the umbrella of FPO. They made a firm M/s Jai Kisan Engineering works, Salotoya, Jhalawar (Fig. 1).

Table.1 Income earned by youths through service providing at different sites

\begin{tabular}{|c|c|c|c|c|c|}
\hline S. No. & Name of Work & Institution/ Farmer & Youths & Mandays & $\begin{array}{l}\text { Income } \\
\text { (Rs.) }\end{array}$ \\
\hline 1 & $\begin{array}{l}\text { Repair and Maintenance of } \\
\text { Poly house }\end{array}$ & ARS, Ummedganj, Kota & 4 & 40 & 30000 \\
\hline 2 & Construction of Poly house & $\begin{array}{l}\text { Farmers field at } \\
\text { Ramganjmandi }\end{array}$ & 8 & 120 & 80000 \\
\hline 3 & Staking structure work & ARS, Kota & 3 & 09 & 90857 \\
\hline 4 & Fitting of Shade net & Pipadham, Jhalawar & 3 & 03 & 2280 \\
\hline 5 & Fitting of Shade net & $\begin{array}{l}\text { Roopnagar Goshala, } \\
\text { Jhalawar }\end{array}$ & 3 & 06 & 4000 \\
\hline 6 & $\begin{array}{l}\text { Repair and Maintenance of } \\
\text { Poly house }\end{array}$ & KVK, SawaiMadhopur & 6 & 48 & 40000 \\
\hline 7 & $\begin{array}{l}\text { Relocation and repair of } \\
\text { Shade net unit }\end{array}$ & $\begin{array}{l}\text { IIRD, Jhalarapatan, } \\
\text { Jhalawar }\end{array}$ & 7 & 70 & 36400 \\
\hline 8 & Fitting of Shade net & $\begin{array}{l}\text { Farmers field, Munderi, } \\
\text { Jhalawar }\end{array}$ & 3 & 09 & 7700 \\
\hline 9 & Shadenet House New & $\begin{array}{l}\text { Jain Irrigation, Kotara, } \\
\text { Udaipur }\end{array}$ & 12 & 360 & 140000 \\
\hline 10 & Polyhouse repair (1000sqm) & $\begin{array}{l}\text { Gomati Chouraha, } \\
\text { Rajsamand }\end{array}$ & 8 & 240 & 55000 \\
\hline 11 & $\begin{array}{l}\text { Repair and Maintenance of } \\
\text { Net house }\end{array}$ & KVK, SawaiMadhopur & 4 & 8 & 8000 \\
\hline 12 & Polyhouse & CHF, Jhalawar & 10 & 80 & 66000 \\
\hline 13 & Shadenet house & CHF, Jhalawar & 8 & 96 & 50000 \\
\hline 14 & Shadenet house new & Gurukripa nursery, Indore & 35 & 32 & 180000 \\
\hline 15 & Net house repairing & KVK, Jhalawar & 8 & 8 & 8000 \\
\hline 16 & Nethouse repairing & Kashyapmohalla, Jhalawar & 4 & 1 & 4940 \\
\hline 17 & Poly house repairing & Mount Abu, Sirohi & 3 & 3 & 11500 \\
\hline 18 & Poly house repairing & Udaipur & 8 & 24 & 21000 \\
\hline 19 & Shade net house renewal & Dungarpur & 20 & 31 & 360000 \\
\hline & \multicolumn{2}{|c|}{ Total income after completion of training } & 157 & 1188 & 1195677 \\
\hline
\end{tabular}




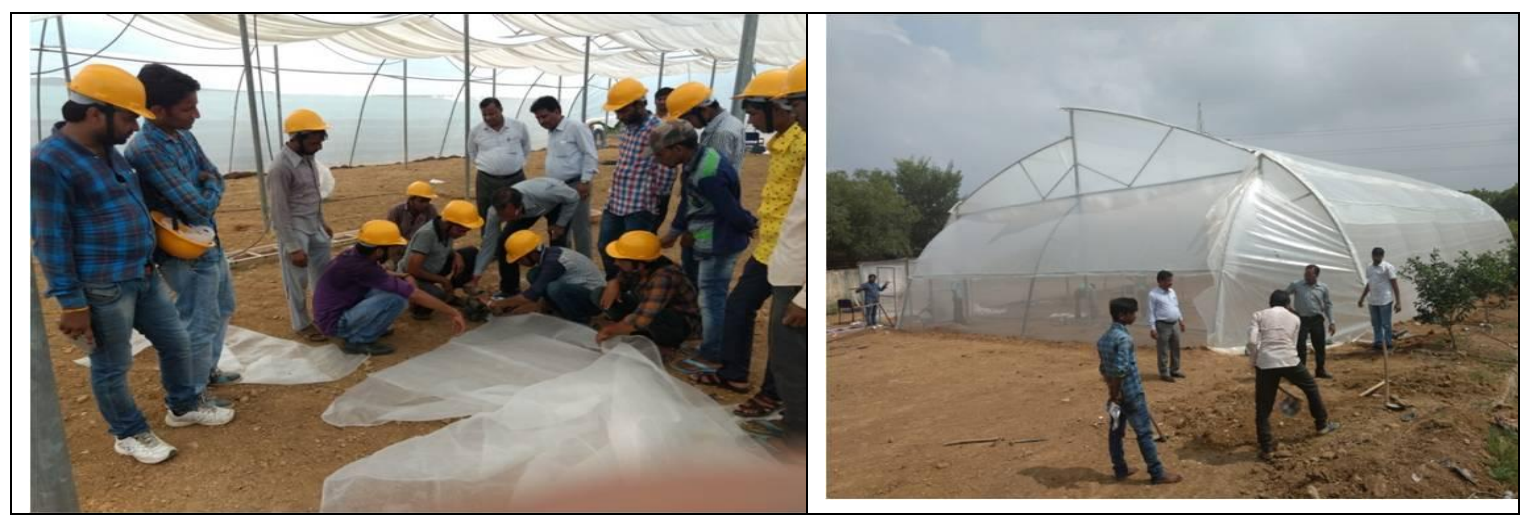

Fig.1

About Rs. 1006 per day average earns up to $21^{\text {st }}$ July 2018. The firm earned Rs. 11.95 lakh in the last One and half year by the repairing of dozen of Shade net and Poly house in Rajasthan and Madhya Pradesh. A total of 157 youths were engaged for 1188 days during this duration. Previously, they earned only 250 rupees per day and now they earned additional Rs. 1006 per day income as parttime with agriculture.

Krishi Vigyan Kendra, Jhalawar since its establishment has directed its effort towards agricultural development in the district and bringing about entrepreneurship and skills among practitioners of agriculture and rural to ensure livelihood security.It may be concluded that the repair of the shade net and the poly house can be successfully promoted in the rural area for creating self-employment among rural youth and practicing farmers. Krishi Vigyan Kendras are playing a pivotal role in providing vocational training for generating employment to the rural youth. The majority of bee shade repairs were in the young age group, it is a good sign for generating self-employment for rural youth.

\section{References}

Meena, B.S., Singh G. and Sadhna Pandey (2003), Winter School on Recent Advances in forage production on Degraded. An Evaluation, Ind. Res. J. Ext.Edu. Vol. 3(1): 1-3

Rampal V.K. and Ranwal Mahendra (2004), Satisfaction of trainees of wheat production technology. Agriculture Extension Review 16(4): 21-24.

Joseph, R. (2008) Impact of KrishiVigyanKendra training programme on maize production. Evaluation capacity building in rural resources management: A Manual. Indian Agriculture Research Institute, Pusa, New Delhi.

\section{How to cite this article:}

Meena, R. R., C. B. Meena, K. L. Geanger, A. Kotmire, K. C. Meena and Verma, A. K. 2020. Tripling the Income of Rural Youth through Protected Cultivation Structures Repair: A Success Story. Int.J.Curr.Microbiol.App.Sci. 9(04): 1116-1119. doi: https://doi.org/10.20546/ijcmas.2020.904.132 